\title{
Potential of Batik Semarang in the Protection of Industrial Design in the Perspective of Law Number 31 Year 2000
}

\author{
Rindia Fanny Kusumaningtyas ${ }^{1 \mathrm{a}}$, Aditya Wibowo ${ }^{1 \mathrm{~b}}$ \\ ${ }^{1}$ Faculty of Law, Universitas Negeri Semarang, Semarang (UNNES), Indonesia \\ a rndhukum@gmail.com, ${ }^{\mathrm{b}}$ wibowo.adiitya@gmail.com
}

\begin{abstract}
Batik is one example of art and culture that has a distinctive motif from various regions in Indonesia, and "Semarang Batik" is one of them. "Semarangan Batik" is one of batik art. It is preserved and it is must be protected by legal law because Batik is one of Indonesian's culture heritage. "Semarangan Batik" need attention from Indonesian's Government and others, so that "Semarangan Batik" can not claimed belong of others. As known as Copy Rights Act 28 of 2014 in Indonesia is not maximum as good protection to "Semarangan Batik". In this case, there are some kinds of "Semarangan Batik" motives are not registered copy rights yet. Because "Semarangan Batik"is used as product in industry activity so that "Semarangan Batik"can be protected by Design Industry Act 31 of 2000. The purpose of this case is to give important information about "Semarangan Batik" can be protected by Design Industry Act, and it is to know that existence registration of "Semarangan Batik" and craftsmen problems when they will register theirs motives of the products. In the case we use "Yuridis Empiris" to solve this problem with researching the primary data obtainable from "Semarangan Batik" craftsmen and than the secondary data related Copy Rights Act 28 of 2014 and Design Industry Act 31 of 2000.
\end{abstract}

Keywords-Semarangan Batik, Creation, Design Industry

\section{INTRODUCTION}

Indonesia has a lot of artistic and cultural diversity, where each region has its own characteristics that are different from other regions. The development of technology that is increasingly fast and knowledge that increasing rapidly are require the existence of a legal protection for the artwork, so it cannot claimed or claimed by other parties / regions. One example of artwork that must get legal protection is the Semarangan Batik artwork that is typical of Semarang City.

Batik needs to get protection because batik is a work of creation that requires mind, energy and time as an intellectual property. Protection of intellectual artworks is protected under intellectual property laws specifically set about works of art, namely Act No. 28 year 2014 about Copyright, one that is protected is a masterpiece the art of batik in Article 40 letter $j$ that mention that batik works of art or the other motifs as artistic creation are protected.

Associated with the element of beauty or aesthetics in works of art is actually more appropriate if associated with Copyright, because the scope of the Copyright of its own, one of which is the art that there is always the preferred aesthetic value. As an example of batik motifs that became the hallmark of an area such as batik motif of Semarang. Until now, the development of related research ever undertaken on the protection of batik Semarang results haven't been fullest due understanding of batik artisans still very minimal Copyright registration associated with batik motif and ignorance of the craftsmen to register the motif of batik, Batik Semarang protection so that it also hasn't been fullest so that possible impersonation of batik motif of Semarang.

Development of Batik Semarang has become the industrial product that needs special attention is related to its protection in order to make batik motif Semarang not claimed or emulated by other regions. Because it is possible the batik artwork made by craftsmen to the industrial activities that could be useful and utilized by society at large.

In this case, Batik motif of Semarang could be protected by industrial design legislation, namely Act No. 31 of Year 2000, because the products batik Semarang as two dimensional form of the composition of the line pattern on the fabric that gives the impression of aesthetically, with in other words, the work is copyrighted the batik art of applied artwork is used to produce the products, goods, commodities, industrial or handicraft. (Article 1, paragraph 1 of Law No. 31 of 2000 about Industrial Designs) One form of such product or handicraft one is a batik patterned fabrics.

Through the protection of the Industrial Design batik works of art that aims to achieve justice for all parties, namely the creation of a balance of interests between the creators of batik works of art with other community interests. The expected outcomes cultural creatives nation Indonesia, including traditional batik, art can exist and provide opportunities to compete in the era of globalization. Basing on the description above, it may be understood that the problems in the protection of works of art of batik is yet of the existence of an appropriate protection system to protect traditional batik works of art and the craftsmen who produce they work can be classified 
in copyright. The problem that is examined related to the potential of Semarangan Batik to protect Industrial Design is: (1) how the existence of artwork Bagik Semarangan as industrial design creations of two-dimensional products produced batik in Semarang? And (2) how is the Legal Protection given to the creation of Batik Semarangan artwork reviewed in accordance with Act Number 31 of 2000 about Industrial Design?

\section{RESEARCH METHOD}

The method of the approach used in this study is the empirical such as juridical ways or procedures used to solve the problem of research examining secondary data first to then proceed with researching primary data that is in the field. Primary data is data obtained directly from the community. Juridical aspect is used as a reference in judging or analyzing problems based on aspects of the law that is to examine the rules of law that have a correlation with this research.

While the empirical approach is to conduct research aimed at obtaining empirical knowledge by way of plunging directly into the field about everything related to the legal protection of works of batik motif of Semarang. So it is a juridical approach to empirical research that examines the legal regulations which are then associated with the data and behavior of living amidst society directly.

Types of data used in this research is the primary data and secondary data. Primary data is data that is retrieved from the location of the research. While secondary data is data that can support the information or support primary data completeness. Secondary data source obtained from the Legislation, a reference book or other communication and information media.

Methods of data analysis used is qualitative method, that data obtained are arranged systematically analyzed then qualitatively in order to obtained the clarity issues that are discussed. The purpose of this qualitative analysis is used to get information about the outline of the issues that will be examined in this study.

The qualitative methodology is a procedure that produces research descriptive data in the form of the written word or spoken of people and behavior that can be observed. After data analysis is finished, the results will be presented in a descriptive with speak and describing what it is in accordance with the problems examined. From the results are then drawn the conclusion that is the answer to the problems raised in this research.

\section{III.RESULT AND DISCUSSION}

\section{A. The existence of works of art of Batik Semarang as creations of a two-dimensional Industrial Design Products produced by Batik Craftsmen in Semarang}

Batik as a work of art that is displayed in a piece of cloth can produce a variety of batik motifs. The manufacturing process is also a development of traditional techniques to modern techniques by cap and printing. This development is not without reason, because the usual activities performed by women who live in the royal period to fill the spare time. This is usually done by the wife of the king to make batik which will be presented by the king as the expression of a wife's feelings to real. And now, Batik demand as the needs of the community is very high for office uniforms, school uniforms and other needs. By studying batik demand by the community then developed batik making in a modern way to make more quickly the production of batik.

In addition to batik performed by the wife of the king, also commonly done by servants in the kingdom because the king's order to make batik according to the desired king. The production of royal batik produces various types of batik motifs that contain a meaning of philosophical value, historical value and religious value.

Traditional batik that developed first began to demand by the public because of the impression of aesthetics that can be seen with the eyes and has a value of usefulness. Batik making, takes a long time and the price is more expensive than batik made using modern techniques. Traditional batik was made by human resource and using natural ingredients such as plants as a color, and batik making in modern use machine or stamp patterned batik by using artificial coloring material.

One of batik art work is Batik Semarangan, where its motif is characterized by icon of Semarang City such as Lawang Sewu, Tugu Muda, Warag Ngendog, Blekok Bird, Greg Blendug, Gambang Semarang, Godhong Acid, Flower and Acid Fruit which consistently developed batik craftsmen at 16 District Semarang City, not only the motives characterized by Semarang City but also there are rambutan fruit motifs, durian fruit and fruit kolang-kaling, and siwarak Gunungpati. According to what is explained by Umi, the owner of Salma Batik further develops batik motifs that are characterized by the typical of Gunungpati subdistrict, namely rambutan and durian fruits motif to better known the people that the motif is also a typical Batik Semarangan motif, because Gunungpati District is part of Semarang City.

This is in accordance with the results of research that shows that the craftsmen not only make the motifs that have been known to the public in general, but began to develop other motifs that characterize the area of the district in the city of Semarang. Some batik artisans who successfully asked for opinions related to Batik Semarangan say that Batik Semarangan there are made traditionally because they want to create a standard motif and can not be changed while modern batik motifs can be modified depending on the creator's desire and creativity.

Batik Semarangan produced by the craftsmen in the city of Semarang also has the difference between one craftsman with other craftsmen although the same batik motif. Both in terms of shape motive pictures, coloring and modification of batik motifs. When compared with batik motif produced by other cities such as Solo, Pekalongan, and Yogyakarta that batiknya motif is standard or grip means people already know that the motive of the city.

The current development of Batik Semarangan into industrial products as handicrafts, cloth products and batik clothes, therefore Batik Semarangan as a two-dimensional creations can be protected under the Industrial Design Act. 
The definition of industrial design itself is a creation of the form, configuration, or composition of lines or colors, or lines and colors, or a combination thereof in the form of three-dimensional or two-dimensional that gives the impression of aesthetic and can be realized in threedimensional or two-dimensional patterns and can be used to produce a product, goods, industrial commodity, or handicraft (Article 1 point 1 of the Industrial Design Law). Based on the World Intellectual Property Organization (WIPO) as an industrial design product must also meet the requirements of among others can be seen, has a special appearance, protecting the aesthetic aspect of outer appearance, and has a useful value.

Associated with the work theory that Batik Semarangan as a work of art raises the power (rights) for artisans of creation, design motifs made for his own use with economic goals and give permission to others to use the creation of batik motif made by craftsmen. Batik Semarangan as a work of art creations of images on cloth is also an applied art that is a work of art that is made by applying art on a product so as to have aesthetic impression in fulfilling practical needs such as the use of pictures, motifs, or ornaments on a product, such as Batik Semarangan as a suatukreasi industrial design that gives the impression of aesthetic composition of the line of twodimensional ornaments such as patterns, drawings, motifs embodied in handicraft products and batik cloth.

The existence of Batik Semarangan developed by the craftsmen in the city of Semarang, this is realized by holding and following various events such as fashion shows to introduce batik motifs typical semarangan as already followed by Batik Razaqa to display the design of batik clothing that is made as well as showing the characteristics typical batik motifs are more dominant in black and red. Unlike the Batik Zie has a characteristic of batiknya motifs using natural coloration of mangrove plants that produce brighter colors with various motifs produced such as mangrove ecosystem motifs, motifs asem purnomo, gambang dancer motif Semarang, and motifs warak kencana. (Interview Results with Semarangan Zie Batik Craftsmen and Razaqa Batik, May 11 2018)

In addition, craftsmen in cooperation with the Government of Semarang City and companies in the city of Semarang in the manufacture of batik uniform typical semarangan used on certain days according to the rules. The demand of Batik Semarangan made in the design of clothing and handicrafts proves that Batik Semarangan actually much in demand by the community, but every motive produced by the craftsmen do not have a standard motif at all arbitrary, by karenanyasemak craftsmen make the same batik motifs that become the icon of Semaranghanya City which distinguishes from additional modifications to the motive and color.

This makes the creation of Batik Semarangan motifs are still visible so that the public interest in the motive of Batik Semarangan is still very low. Pengarajin Batik Semarangan not give up by taking steps to form clusters or groups of artisans Batik Semarangan whose members are batik craftsmen from 16 districts in the city of Semarang.
Some members of about 40 people entrust their batik work in Srondol Market is a government-owned market specifically intended for small medium enterprises (SMEs) to sell and market their products including Batik Semarangan products to be more widely known by the people, especially tourists who come to Semarang. (Interview Results with Mrs. Novi Razaqa owner and Vice Chairman of the Cluster Batik Batik Semarangan, May 11, 2018) However, the existence of this Srondol Market has not been able to guarantee the marketing of Batik Semarangan products, it's just that the craftsmen are sure when the existence of Srondol Market is promoted by Semarang City Government by inviting tourists from outside Semarang City to come see the products of UMKM that are sold so that there will be tourist attraction to buy batik products in the form of clothing or batik cloth as a souvenir from the City of Semarang.

\section{B. Legal Protection That Given For The Creation Of The Art Of Batik Semarang in Terms of Act No. 31 of The Year 2000 on Industrial Design}

A work from the creator or designer should get legal protection based on the theory of creation. (H.R, 2011:2) Legal protection is the Government's attempt, or non government in protecting the objects owned by a human being or group of human beings to get the rights. Protection has elements of what is protected, how to protect, what kind of action to protect.

Industrial Design is part of the intellectual property. The protection of the industrial design is based on the concept of the thought that the birth of industrial design is inseparable from the ability of creativity, taste and karsa owned by men. According to Bruce Archer, industrial design is a product of human intellectual, human product. Specifically, the configuration associated with the design, composition, value, meaning, and purpose of a man-made phenomenon. In a broad sense, the design includes product design, textiles, interior, graphic design, architecture, engineering, design and the city.

In this sense it appears that one of the design industry is a form creation, configuration and composition of lines or colours that give the impression of aesthetically and can be used to produce handicrafts. It is obvious, that the industrial design is produced by craftsmen in fact included in the scope of industrial design as formulated in the Industrial Design Act [4].

Anis Mashdurihatun and M. Ali Mansyur said that, there is an ambiguous relationship between copyright rights and design rights caused by the design, such as a blue print of the appearance of certain products included in the artwork for the acquisition of copyright. If the artwork is used as a blue print for the manufacture of a product, the holder of the artwork also has the copyright for the creation of his artwork. For example, a person designs a fantastic carved chair on paper. If the new design is registered, then the design's creator is entitled to the design. In addition, these creations can be judged as a work of art that he makes chair based on the design, also will own the copyright to the chair.Lalit Jajpura and others 
said, that Industrial Design is used to protect an ornament or display from a mass-produced product [14].

Industrial design is closely related to the activities of industry and trade. Businessmen can be divided into two (2) such as UMKM-IKM (Usaha Mikro Kecil dan Menengah-Industri Kecil Menengah) and non-UMKN that based on a capability in terms of creating business activity, this ability requires the presence of creativity and innovation continuously to find something different from the previously existing. (Kasmir, 2016: 22) On the development of the moment, that the public is more interested in buying products with brands that are not original but have the same design with the design of the original product.

The Batik craftsmen Semarang as businessmen UMKM sometimes experience a constraint in protecting his batik motifs. Such barriers may arise due to internal factors such as the expensive registration fees, registration requirements is difficult and the awareness of the importance of registration of batik artisans motifs are still insufficient, as well as external factors, namely the lack of dissemination of relevant parties, namely the Directorate General of intellectual property registration related motifs Semarang to get legal protection.

Legal protection of industrial design is very important, not only because it is in the interest of designers but is intended to develop the creativity of designers to continuously invent new design. The legislation does not mention all of the industrial designs industrial design can be protected legally, only industrial design that has a newness that can be protected.

Batik Semarangan had a very important role in advancing the country's industrial sector with Indonesia improve competitiveness by leveraging the role of the industrial design that is part of the intellectual property rights, cultural diversity combined with an effort to participate in the globalization of Commerce by providing legal protection of national industrial design[8].

Based on the theory of legal protection, according to [2], always related to the power. There are two powers that is always a concern i.e. the authority of Government and economic power. In relation to the powers of the Government, the issue of legal protection for the people (ruled), against the Government (ruling) in connection with economic power. Problems of legal protection is protection for the weak (economic) against the strong (economic). (1987: 2-5) Therefore, accordance with this theory that the crucial legal protection given to the Batik craftsmen Semarang as the perpetrator of the UMKM efforts in this regard as the person who has the status of a weak compared to large companies that have revenue far more than with the perpetrators of the UMKM, so be aware of the related registration fees application for intellectual property into its own constraints Semarang Batik for craftsmen to obtain legal protection.

Industrial Design produced by a designer, then it is worth to be given legal protection. Legal protection is given so that the resulting industrial design craftsmen are not replicated or utilized by other parties who are not entitled to. For industrial design industrial design can be protected should they meet several criteria. The criteria are intended to include on: first, the new industrial design means not existing disclosure; Second, it is not contrary to morality/decency; Third, an industrial design/some industrial design industrial design is one of unity that has the same class and; Fourth, the registered industrial design are not pulled back to the applicant [9]. The fourth criteria has been met, then industrial design can be registered.

Batik Semarangan had to get legal protection because, according to Robert M. Sherwood there are several theories of the intellectual property underlying the need for legal protection of Batik Semarangan :

1. Reward theory, which has a very deep meaning in the form of recognition of intellectual works that have been produced by a person to the inventor/creator or designer should be given awards in return for efforts creative in finding/creating the intellectual works; Batik Semarangan be included as a category of intellectual property, since batik craftsmen in creating or designing requires an idea which could be poured in the form of art images on a piece of cloth, not just craftsmen also takes time and also the energy a bit. It is therefore against the results of the work of the craftsmen must be appreciated in the form of appreciation in return for his work.

2. Incentive theory, the theory is in line with the theory of reward, which associate the development of creativity by providing incentives for the inventor/creator or designer. Based on this theory needs to be given incentives to seek terpacunya the next research activities and useful; Batik Semarangan that has already produced by the craftsmen of course expected to gain economic value for Semarang, Batik craftsmen because of the raw materials used to make a batik works of art need not cost a bit.

3. Risk theory, this theory acknowledges that the industrial design is a masterpiece containing risks that can allow other people who first discovered the way or fix it and thus it is fair to give a form legal protection of an effort or activity containing the risk. Sherwood contend that the risks which may arise from the use of illegally will result in losses in economic and moral for the creator/designer can be avoided if there is a strong legal basis for protecting designs the industry.

Batik Semarangan that has many motifs characterized by Semarang is possible can be imitated by others nor recognized as belonging to other areas, therefore protection against Semarang Batik is very important to prevent the occurrence of recognition Semarang motifs against ownership by other In addition, the underlying Batik Semarang have to be registered to get legal protection was the existence of some of the principles contained in the intellectual property satunyaadalah of the economic principle of wrong such as intellectual property has its benefits and economic value as well as useful for human life. On the economic value of intellectual property as an industrial design is a form of wealth for the owner, creator/designer benefit from ownership toward his work such as in the form of royalty payments or benefits from sales of Batik Semarang. The principle of economy the 
rights such as derived from the intellectual creative activities a willingness of the human intellect that is expressed in various forms that will give an advantage to the owner of the corresponding.

So it is obvious that Batik Semarang as a creative industrial design products 2-dimensional form of handicraft products as well as textile products that could be of benefit to the wider community and used in industrial activity could be protected with Act No. 31 of the year 2000 on industrial design in addition to the legal protection afforded by the Act No. 28 year 2014 about copyright as a work of art copyrighted the batik or other motifs of art set in article 40 the letter $\mathrm{j}$ and as the applied arts are regulated in article 40 the letter $g$ automatically based on declarative principle of the protection of copyright law because registration is not a must, and this is different from the design industry who hold prinsipkonstitutif that to get the legal protection must be registered in advance considering the industrial design rights are obtained when it was registering and this is inextricably linked that Batik Semarang in accordance with its development into a product that is produced in the industrial activity.

Batik Semarangan as applied in fact already get legal protection automatically based on Copyright law, but due to design differences Semarang Batik have batik motif with other regions then can be given based on the protection of the industrial design Act. Industrial design itself is only specifically protect the outward appearance of a product which can be clearly seen, have a special appearance, there is the impression of aesthetics and usability have to be applied to the goods. As well as the Batik Semarangan can be seen, has distinctive motifs, there is the impression of estetispada every motive and have usability applied handicraft products batik fabric or clothing or.

Industrial Design is a branch of intellectual property matters in the world of industry, therefore need to be registered to the industrial design Office (Director General of the Ministry of Justice and Human Rights of Republic of Indonesia) to gain the protection of the law firmly and real, especially against the Semarang became Batik batik the city of Semarang.

\section{CONCLUSION}

The existence of Semarangan batik as a product of industrial design is growing because of the many requests from the society that can be increasing the production of batik semarangan. Because of the support from the Government that provides a place to market batik production semarangan. Semarang batik can be protected by the Law of Indsutri Design because of the following elements: (1) Semarangan Batik can be seen clearly; (2) Having a special appearance (pattern or motif); (3) Has an aesthetic value; and (4) Has usability that can be applied to handicraft and clothing products. Semarangan batik motif has a different design motif from other regions, therefore it is necessary to get legal protection by industrial design act because is devoted to the appearance of industrial design products, including one of them is semarangan batik.

\section{REFERENCES}

[1] Soeparman, Andrieansjah. Hak Desain Industri Berdasarkan Penilaian Kebaruan Desain Industri. Bandung: P.T. Alumni, 2013.

[2] Hadjon, Philipus M. Perlindungan Hukum Bagi Rakyat Indonesia. Surabaya: PT. Bina Ilmu, 1987.

[3] H.R, Ridwan.. Hukum Administrasi Negara.Jakarta:PT Raja Grafindo Persada, 2011

[4] Maulana, Insan Budi. A-B-C Desain Industri: Teori dan Praktek di Indonesia. Bandung : PT Citra Aditya Bakti, 2011.

[5] Utomo, Tomi Suryono. Hak Kekayaan Intelektual (HKI) di Era Global. Yogyakarta: PT Graha Ilmu, 2010

[6] Saidin, O.K. Aspek Hukum Hak Kekayaan Intelektual (Intellectual Property Right). Jakarta: PT Raja Grafindo Persada, 2013.

[7] Kasmir. Kewirausahaan. Jakarta: PT Rajagrafindo Persada, 2016.

[8] Muhammad, Abdulkadir. (2001).Kajian Hukum Ekonomi HKI. Bandung: PT Citra Aditya Bakti, 2001

[9] Sudaryat. Hak Kekayaan Intelektual. Bandung: Oase Media, 2010

[10] Djumhana,Muhammad dan R. Djubaedillah. Hak Milik Kekayaan Intelektual (HAKI:Peraturan Baru Desain Industri). Bandung: PT. Citra Aditya Bakti, 2003

[11] Act No. 28 of The Year 2014 about Copyright

[12] Act No. 31 of The Year 2000 about Industrial Design

[13] Mashdurihatun, Anis and M. Ali Mansyur. (2017). Product Capabilities Dynamic on Industrial Design Carved Wood in Small and Medium Enterprises (SMES) Jepara Furniture in Promoting the Protection of Intellectual Property Rights. International Journal of Applied Engineering Research ISSN 0973-4562 Volume 12. No. 19 (2017). pp. 8217-8226

[14] Jajpura, Lalit, Bhupinder Singh and Rajkishore Nayak. (2017). An Introduction to Intellectual Property Rights and their Importance in Indian Context. Journal of Intellectual Property Rights Vol. 2. pp. 31-41 